$\mathbb{T}$ periodica polytechnica

Chemical Engineering $52 / 1(2008) 23+28$

doi: 10.3311/pp.ch.2008-1.05

web: http://www.pp.bme.hu/ch

(c) Periodica Polytechnica 2008

RESEARCH ARTICLE

\section{Liquid-liquid extraction of sulfuric acid using tri-n-dodecylamine/kerosene}

Jamal Stas

Received 2007-01-18

\section{Abstract}

The extraction of sulfuric acid has been investigated by tri$n$-dodecylamine $(\overline{T D A})$ in kerosene in the presence of octanol1 as modifier. The effect of octanol-1 has been studied on the equilibrium constant of $(\mathrm{TDAH})_{2} \mathrm{SO}_{4}$ and $\mathrm{TDAHHSO}_{4}$ formation in the concentration range from 5 to $25 \% \mathrm{v} / \mathrm{v}$ and within the temperature range from 25 to $50{ }^{\circ} \mathrm{C}$. The equilibrium constants $\left(K_{1}\right.$ and $K_{2}$, at $\left.25^{\circ} \mathrm{C}\right)$, the enthalpy $\left(\Delta H_{1}^{\circ}, \Delta H_{2}^{\circ}\right)$ and the entropy $\left(\Delta S_{1}^{\circ}, \Delta S_{2}^{\circ}\right)$ changes were calculated for two extraction reactions of sulfuric acid by tri-n-dodecylamine containing $10 \%$ octanol-1 and they were found to be $10^{9.642} \mathrm{l}^{4} / \mathrm{mol}^{4}, 10^{-0.899}$ l/mol, -99.11, -22.17 kJ/mol, -0.149, -0.063 kJ/mol.K, respectively. The two reactions are:

$$
2 \overline{\mathrm{TDA}}+2 \mathrm{H}^{+}+\mathrm{SO}_{4}^{2-} \stackrel{K_{1}}{\rightleftarrows} \overline{(\mathrm{TDAH})_{2} \mathrm{SO}_{4}}
$$

and

$$
\overline{\left(\mathrm{TDAH}_{2} \mathrm{SO}_{4}\right.} \mathrm{H}^{+}+\mathrm{HSO}_{4}^{-} \stackrel{K_{2}}{\rightleftarrows} 2 \overline{\mathrm{TDAHHSO}_{4}} .
$$

\section{Keywords}

Liquid-liquid · extraction · sulfuric acid · tri-n-dodecylamine/kerosene

\section{Acknowledgement}

The author wishes to express his thanks to Prof I. Othman, Director General of Syrian Atomic Energy Commission for support and encouragement and to Prof. G. Zayzafoon, head of Chemistry Department for fruitful discussions.

\section{Jamal Stas}

Department of Chemistry, Atomic Energy Commission,, P.O.Box 6091 Damascus, Syria

\section{Introduction}

Tertiary amines dissolved in aliphatic diluents such as kerosene have been widely and satisfactorily used in the extraction of numerous metal ions such as uranium(VI), molybdenum(VI), tungsten(VI), chromium(III, VI), and vanadium(V) from sulfate and sulfuric acid solutions, due to their reasonable cost, and high yield, as a result of solubility or degradation properties [1-6]. In this process the partition of sulfuric acid between water and tertiary amine is very important because the extraction procedure of metal ions is usually started by reacting the free amine with sulfuric acid to form an amine salt, as described in the two following equations [7, 8]:

$$
\begin{aligned}
2 \overline{\mathrm{R}_{3} \mathrm{~N}}+\mathrm{H}_{2} \mathrm{SO}_{4} & \rightleftarrows \overline{\left(\mathrm{R}_{3} \mathrm{NH}\right)_{2} \mathrm{SO}_{4}} \quad \text { and } \\
\overline{\mathrm{R}_{3} \mathrm{~N}}+\mathrm{H}_{2} \mathrm{SO}_{4} & \rightleftarrows \overline{\mathrm{R}_{3} \mathrm{NHHSO}_{4}},
\end{aligned}
$$

where the superscript bar refers to the organic phase. In the second step the amine salt extracts the metal sulfate complexes in an adduct or anion-exchange reaction as follows [1-3, 3$]$ :

$$
\begin{aligned}
\overline{\left(\mathrm{R}_{3} \mathrm{NH}\right)_{2} \mathrm{SO}_{4}}+\mathrm{MSO}_{4} & \rightleftarrows \overline{\left(\mathrm{R}_{3} \mathrm{NH}\right)_{2} \mathrm{M}\left(\mathrm{SO}_{4}\right)_{2}}, \\
\overline{\left(\mathrm{R}_{3} \mathrm{NH}\right)_{2} \mathrm{SO}_{4}}+\mathrm{M}\left(\mathrm{SO}_{4}\right)_{2}^{2-} & \rightleftarrows \overline{\left(\mathrm{R}_{3} \mathrm{NH}\right)_{2} \mathrm{M}\left(\mathrm{SO}_{4}\right)_{2}}+\mathrm{SO}_{4}^{2-} .
\end{aligned}
$$

Unfortunately, mixing tertiary amine/aliphatic diluent with sulfuric acid gives a third phase, which is not tolerated in solvent extraction processes, but the addition of a small amount of longchain alcohols to the tertiary amines will prevent third-phase formation without affecting much the metal ion extraction or phase disengagement [7,8].

In the present paper we report the partition of sulfuric acid between water and tri-n-dodecylamine containing octanol-1 in kerosene and the effect of octanol-1 and temperature on the extraction constant of sulfuric acid with tri-n-dodecyl amine/kerosene.

\section{Experimental}

Tri-n-dodecylamine ( $\overline{\text { TDA }}$ ) used as an extractant was obtained from MERCK (95\% purity). The diluent used was the kerosene PEMCO SOLV 110 from PEMCO Chemicals company having a density of $800-810 \mathrm{~kg} / \mathrm{m}^{3}$ at $15^{\circ} \mathrm{C}$, a boiling point 
range $200-250{ }^{\circ} \mathrm{C}$, a flash point $>70{ }^{\circ} \mathrm{C}$, and aromatic content of $\max 0.5 \%(\mathrm{v} / \mathrm{v})$. Octanol-1 used as a modifier was obtained from MERCK (96\% purity).

Sodium hydroxide ampule from BDH containing a concentrated solution of $\mathrm{NaOH}(2 \mathrm{~N})$ was used for the preparation of $0.1 \mathrm{~N} \mathrm{NaOH}$ by dilution the content of the ampule to $1 \mathrm{~L}$ with double distilled water.

The aqueous solutions of sulfuric acid were prepared by diluting concentrated sulfuric acid (from FLUKA, 95-97\%) with double distilled water.

The extraction was carried out by stirring equal volumes ( 25 $\mathrm{mL}$ ) of aqueous and organic phases in a thermostated water bath; the mixtures were separated after $30 \mathrm{~min}$ of decantation.

The distribution coefficient $\left(\mathrm{K}_{d}\right)$, was calculated as the ratio:

$$
\begin{aligned}
& K_{d}= \\
& \text { Total concentration of } \overline{\mathrm{H}_{2} \mathrm{SO}_{4}} \text { in the organic phase at the equilibrium (M) } \\
& \overline{\text { Total concentration of } \mathrm{H}_{2} \mathrm{SO}_{4} \text { in the aqueous phase at the equilibrium (M) }}= \\
& \overline{\left[\mathrm{H}_{2} \mathrm{SO}_{4}\right]_{t}} \\
& \overline{\left[\mathrm{H}_{2} \mathrm{SO}_{4}\right]_{t}}
\end{aligned}
$$

The concentration of sulfuric acid in the aqueous and organic phase solutions was measured using an automatic potentiometric titrator (AT-420N-WIN) from KYOTO ELECTRONICS, Japan. The potentiometric measurements were carried out in a thermostated jacketed cell at $25{ }^{\circ} \mathrm{C}$. A known volume of the aqueous phase ranging from $(0.5$ to $1 \mathrm{~mL})$ was diluted with deionized water, magnetically stirred, then a small amount of $0.1 \mathrm{~N}$ of sodium hydroxide was added using a motorized piston burette to achieve reproducible and accurate titration. KEM combined glass electrode $\mathrm{C}-172$ was used for the $\mathrm{pH}$ measurements during the titration. A graphical plot of the $\mathrm{pH}$ versus titrant volume is automatically done, and also the endpoint is given. A known volume of the organic phase is transferred after the extraction to the titration cell, then $50 \mathrm{~mL}$ of $80 \%$ absolute ethanol in water was added and magnetically stirred to obtain a homogeneous phase, finally the titration was done by $0.1 \mathrm{~N}$ of sodium hydroxide in the same way as described above.

\section{Results and Discussion}

\subsection{Mixing time effect}

Equal volumes $(25 \mathrm{~mL})$ of $0.1 \mathrm{M} \overline{\mathrm{TDA}} /$ kerosene containing $10 \%$ octanol-1 and $0.41 \mathrm{M}$ sulfuric acid were mixed together at $25{ }^{\circ} \mathrm{C}$ for various time lengths. Fig. 1 shows the variation of the distribution coefficient of sulfuric acid against time. It is clear that 5 minutes is the minimum time required to reach the equilibrium.

\subsection{Isotherm of sulfuric acid extraction}

The extraction of sulfuric acid was examined in the concentration range of (0.02-4 M) by 0.1 M tri-n-dodecylamine /kerosene containing $10 \%$ octanol- 1 as modifier at an organic to aqueous phase ratio $\left(\mathrm{V}_{\text {org }} / \mathrm{V}_{\mathrm{aq}}=1\right)$, and at $25^{\circ} \mathrm{C}$. The results are shown in Fig. 2. The concentration of sulfuric acid in the organic phase increases with increasing the concentration of sulfuric acid in the

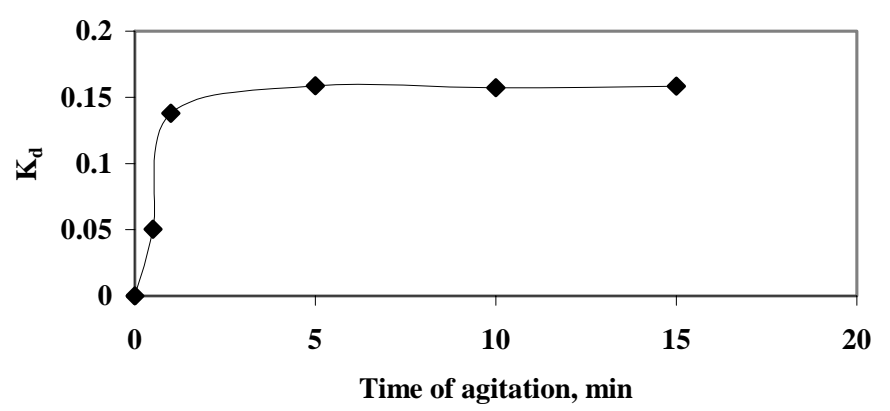

Fig. 1. Effect of time on sulfuric acid extraction. $\overline{[\mathrm{TDA}}_{i}=0.1 \mathrm{M} /$ kerosene $+10 \mathrm{v} / \mathrm{v} \%$ octanol-1, $\left[\mathrm{H}_{2} \mathrm{SO}_{4}\right]_{i}=0.41 \mathrm{M} . \mathrm{V}_{\text {org }} / \mathrm{V}_{\mathrm{aq}}=1, \mathrm{t}=25^{\circ} \mathrm{C}$.

aqueous phase until $2.5 \mathrm{M}$, after this concentration no changes of sulfuric acid concentration in the organic phase have been observed and the ratio ${\overline{\left[\mathrm{H}_{2} \mathrm{SO}_{4}\right]} / \overline{[\mathrm{TDA}]}}_{i} \approx 1$ was determined. This means that one mole of $\overline{\mathrm{TDA}}$ reacts with one mole of $\mathrm{H}_{2} \mathrm{SO}_{4}$ and $\overline{\mathrm{TDAHSO}_{4}}$ is the only species present in the organic phase when the concentration of sulfuric acid in the aqueous phase $\geq$ $2.5 \mathrm{M}$.

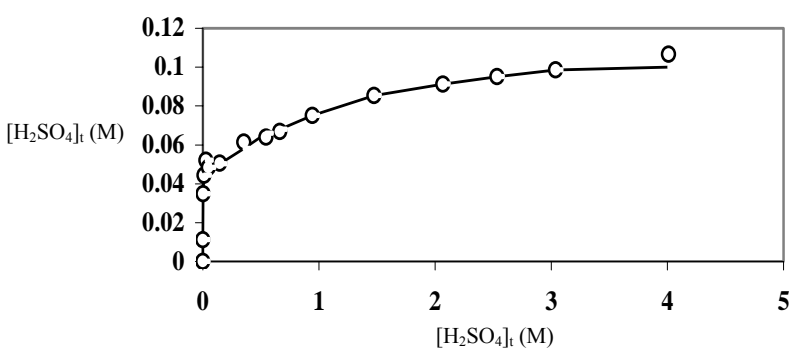

Fig. 2. Variation of sulfuric acid concentration in the organic phase vs. sulfuric acid concentration in the aqueous phase. $\overline{[\mathrm{TDA}}_{i}=0.1 \mathrm{M} /$ kerosene +10 $\mathrm{v} / \mathrm{v} \%$ octanol-1, $\left[\mathrm{H}_{2} \mathrm{SO}_{4}\right]_{i}=$ varies from $0.02-4 \mathrm{M} . \mathrm{V}_{\mathrm{org}} / \mathrm{V}_{\mathrm{aq}}=1, \mathrm{t}=25^{\circ} \mathrm{C}$.

\subsection{Effect of tri-n-dodecylamine on sulfuric acid extraction.}

The extraction of $0.49 \mathrm{M}$ sulfuric acid by various concentrations of tridodecylamine/kerosene containing $10 \%$ octanol-1 was studied at $25{ }^{\circ} \mathrm{C}$ and at an organic to aqueous phase ratio $\left(\mathrm{V}_{\mathrm{org}} / \mathrm{V}_{\mathrm{aq}}=1\right)$. Fig. 3 shows the variation of $\log \mathrm{K}_{d}$ against $\log$ $\overline{[\mathrm{TDA}}_{i}$ which gives a straight line with a correlation coefficient (r) and a slope equal to 0.999 and 1.39 , respectively.

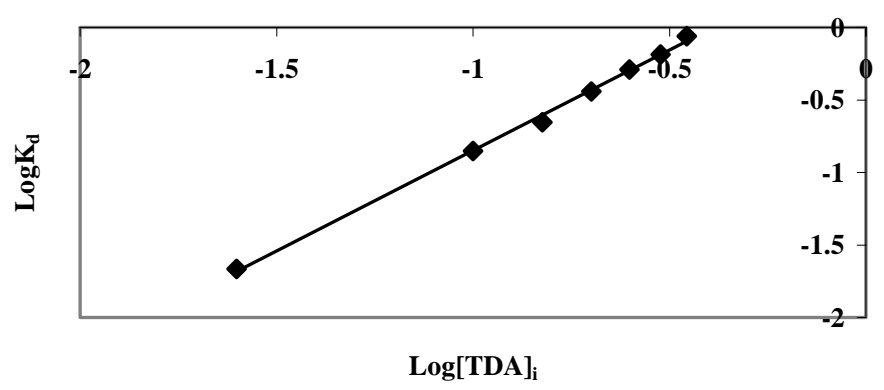

Fig. 3. Variation of $\log \mathrm{K}_{d}$ vs. $\left.\left.\log \overline{\mathrm{TDA}}\right]_{i}, \quad \overline{[\mathrm{TDA}}\right]_{i}=(0.025-0.35 \mathrm{M})$ $/$ kerosene $+10 \%$ octanol- $1 .\left[\mathrm{H}_{2} \mathrm{SO}_{4}\right]_{i}=0.49 \mathrm{M}, \mathrm{V}_{\mathrm{org}} / \mathrm{V}_{\mathrm{aq}}=1, \mathrm{t}=25^{\circ} \mathrm{C}$. 


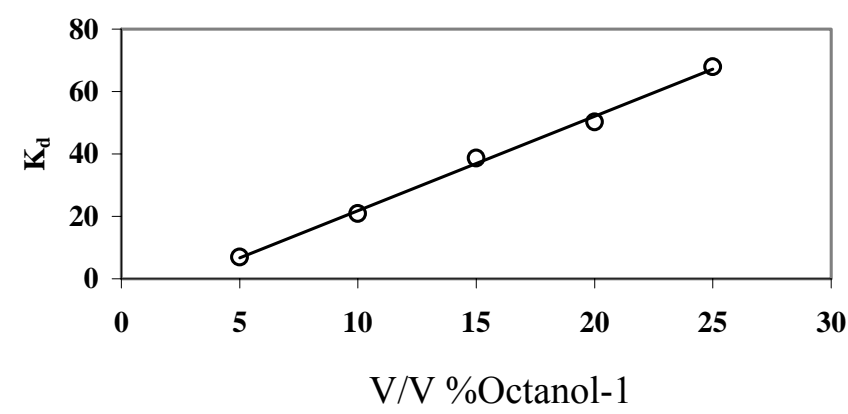

Fig. 4. Variation of the $\mathrm{K}_{d}$ vs. octanol-1 percentage in the organic phase. $\overline{[\mathrm{TDA}}_{i}=0.1 \mathrm{M} /$ kerosene, octanol-1 = varies from 5 to $25 \mathrm{v} / \mathrm{v} \%,\left[\mathrm{H}_{2} \mathrm{SO}_{4}\right]$ $=0.041 \mathrm{M} . \mathrm{V}_{\text {org }} / \mathrm{V}_{\mathrm{aq}}=1, \mathrm{t}=25^{\circ} \mathrm{C}$.

\subsection{Extraction of low sulfuric acid concentration}

3.4.1 Determination of equilibrium constant of $\overline{(\mathrm{TDAH})})_{2} \mathrm{SO}_{4}$ formation $\left(\mathrm{K}_{1}\right)$

The extraction of $0.041 \mathrm{M}$ sulfuric acid by $0.1 \mathrm{M}$ tridodecylamine/kerosene containing 5, 10, 15, 20, $25 \%$ octanol-1 was studied at $25{ }^{\circ} \mathrm{C}$ and at an organic to aqueous phase ratio $\left(\mathrm{V}_{\text {org }} / \mathrm{V}_{\mathrm{aq}}=1\right)$. The low concentration of $\mathrm{H}_{2} \mathrm{SO}_{4}$ was chosen to ensure that all species of sulfuric acid in the organic phase will be in the form of $\overline{(\mathrm{TDAH})_{2} \mathrm{SO}_{4}}$.

Fig. 4 shows the variation of the distribution coefficient of $\mathrm{H}_{2} \mathrm{SO}_{4}$ against octanol-1 percentage in the organic phase, which gave a straight line with a good correlation coefficient and slope equal to 0.998 and 3, respectively.

The following equation describes the formation of $\overline{(\mathrm{TDAH})})_{2} \mathrm{SO}_{4}$ :

$$
2 \overline{\mathrm{TDA}}+2 \mathrm{H}^{+}+\mathrm{SO}_{4}^{2-} \stackrel{\frac{K_{1}}{\rightleftarrows}}{(\mathrm{TDAH})_{2} \mathrm{SO}_{4}} .
$$

The equilibrium constant of Eq. 5 can be written as:

$$
K_{1}=\frac{\overline{\left[(\mathrm{TDAH})_{2} \mathrm{SO}_{4}\right]}}{\left[H^{+}\right]^{2}\left[\overline{\mathrm{TDA}]^{2}}\left[\mathrm{SO}_{4}^{2-}\right]\right.}
$$

From the mass balance of tri-n-dodecylamine the following expression can be written:

$$
\overline{[\mathrm{TDA}]}=\overline{[\mathrm{TDA}]_{i}}-2 \overline{\left[(\mathrm{TDAH})_{2} \mathrm{SO}_{4}\right.}=\overline{[\mathrm{TDA}]_{i}}-\overline{\left[\mathrm{H}^{+}\right]} .
$$

Since,

$$
\overline{\left[(\mathrm{TDAH})_{2} \mathrm{SO}_{4}\right]}=\overline{\left[\mathrm{H}_{2} \mathrm{SO}_{4}\right]_{t}}=1 / 2 \overline{\left[\mathrm{H}^{+}\right]},
$$

the concentration of amine sulfate can easily be determined experimentally by simple titration of sulfuric acid extracted into the organic phase.

In consequence Eq. 6 becomes:

$$
K_{1}=\frac{\overline{\left[\mathrm{H}_{2} \mathrm{SO}_{4}\right]_{t}}}{\left[\mathrm{H}^{+}\right]^{2} \overline{[\mathrm{TDA}]^{2}}\left[\mathrm{SO}_{4}^{2-}\right]}
$$

In the aqueous solution, sulfuric acid ionizes in two steps:

$$
\begin{aligned}
\mathrm{H}_{2} \mathrm{SO}_{4} & \stackrel{K_{a 1}}{\rightleftarrows} \mathrm{H}^{+}+\mathrm{HSO}_{4}^{-}, \\
K_{a 1} & =\left[\mathrm{H}^{+}\right]\left[\mathrm{HSO}_{4}^{-}\right] /\left[H_{2} \mathrm{SO}_{4}\right]=1950 \mathrm{~mol} / \mathrm{L} \text { and } \\
\mathrm{HSO}_{4}^{-} & \stackrel{K_{a 2}}{\rightleftarrows} \mathrm{H}^{+}+\mathrm{SO}_{4}^{2-}, \\
K_{a 2} & =\left[\mathrm{H}^{+}\right]\left[\mathrm{SO}_{4}^{2-}\right] /\left[\mathrm{HSO}_{4}^{-}\right]=0.0126 \mathrm{~mol} / \mathrm{L} .
\end{aligned}
$$

Thus,

$$
K_{a 1} \cdot K_{a 2}=\left[\mathrm{H}^{+}\right]^{2} \cdot\left[\mathrm{SO}_{4}^{2-}\right] /\left[\mathrm{H}_{2} \mathrm{SO}_{4}\right] .
$$

From the mass balance of sulfate we can write:

$$
A=\left[\mathrm{HSO}_{4}^{-}\right]+\left[\mathrm{H}_{2} \mathrm{SO}_{4}\right]+\left[\mathrm{SO}_{4}^{2-}\right],
$$

where $\mathrm{A}$ is sulfuric acid concentration in the aqueous phase.

Ion balance imposes that:

$$
\left[\mathrm{H}^{+}\right]=\left[\mathrm{HSO}_{4}^{-}\right]+2\left[\mathrm{SO}_{4}^{2-}\right] .
$$

From Eqs. 12 and 10 the concentration of $\mathrm{SO}_{4}^{2-}$ and $\mathrm{HSO}_{4}^{-}$can be written as:

$$
\begin{aligned}
{\left[\mathrm{SO}_{4}^{2-}\right] } & =K_{a 1} \cdot K_{a 2} \cdot\left[\mathrm{H}_{2} \mathrm{SO}_{4}\right] /\left[\mathrm{H}^{+}\right]^{2} \text { and } \\
{\left[\mathrm{HSO}_{4}^{-}\right] } & =K_{a 1} \cdot\left[\mathrm{H}_{2} \mathrm{SO}_{4}\right] /\left[\mathrm{H}^{+}\right] .
\end{aligned}
$$

Replacing Eq. 15 and Eq. 16 into Eq. 14 gives:

$$
\left[\mathrm{H}^{+}\right]=K_{a 1} \cdot\left[\mathrm{H}_{2} \mathrm{SO}_{4}\right] /\left[\mathrm{H}^{+}\right]+2 K_{a 1} \cdot K_{a 2} \cdot\left[\mathrm{H}_{2} \mathrm{SO}_{4}\right] /\left[\mathrm{H}^{+}\right]^{2} .
$$

Rearranging Eq. 17]leads to:

$$
\left[\mathrm{H}_{2} \mathrm{SO}_{4}\right]=\left[\mathrm{H}^{+}\right]^{3} /\left(K_{a 1} \cdot\left[\mathrm{H}^{+}\right]+2 K_{a 1} \cdot K_{a 2}\right) .
$$

Finally, replacing Eq. 18 into Eq. 15 and 16 , then introducing it into Eq. 13 the following equation can be obtained after rearrangement:

$$
\begin{aligned}
& {\left[\mathrm{H}^{+}\right]^{3}+K_{a 1} \cdot\left[\mathrm{H}^{+}\right]^{2}+\left(K_{a 1} \cdot K_{a 2}-A \cdot K_{a 1}\right)\left[\mathrm{H}^{+}\right]-} \\
& -2 K_{a 1} \cdot K_{a 2} \cdot A=0 .
\end{aligned}
$$

Thus, knowing the concentration of sulfuric acid in the aqueous phase at the equilibrium (which is done by simple titration) will lead to the possibility of calculation of $\left[\mathrm{H}^{+}\right]$by solving the third degree Eq. 19 , then the concentration of undissociated sulfuric acid $\left[\mathrm{H}_{2} \mathrm{SO}_{4}\right]$ may be derived from Eq. 18 and finally $\left[\mathrm{SO}_{4}^{2-}\right]$ from Eq. 15

The equilibrium constant $\mathrm{K}_{1}$ was calculated from Eq. 9 Fig. 5a. shows that $\log \mathrm{K}_{1}$ increases with the increasing of octanol-1 percentage in the organic phase which is due to the increase of the polarity of the organic phase and dielectric constant. The plot of $\log \mathrm{K}_{1}$ against the inverse of the dielectric constant of our diluent $(1 / \varepsilon)$ gave a straight line with a correlation coefficient and a slope equal to 0.99 and -15.1 , respectively (Fig. 5b). 


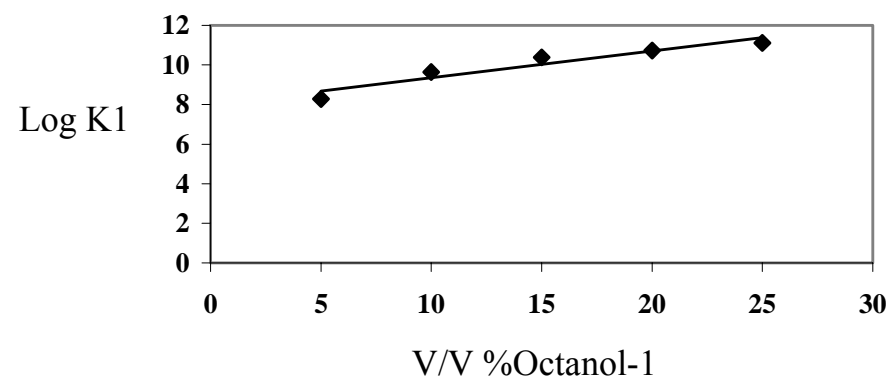

Fig. 5.a. Variation of the extraction constant $\mathrm{K}_{1}$ vs octanol-1 percentage in the organic phase. $\overline{[\mathrm{TDA}}_{i}=0.1 \mathrm{M} /$ kerosene, octanol-1 $=$ varies from 5 to 25 $\mathrm{v} / \mathrm{v} \%,\left[\mathrm{H}_{2} \mathrm{SO}_{4}\right]=0.041 \mathrm{M} . \mathrm{V}_{\text {org }} / \mathrm{V}_{\mathrm{aq}}=1, \mathrm{t}=25^{\circ} \mathrm{C}$.

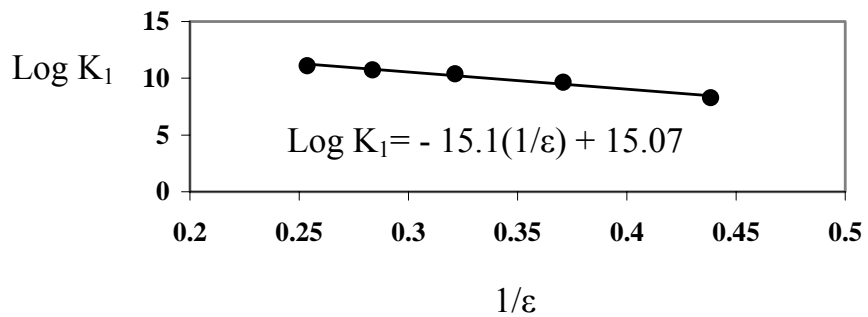

Fig. 5.b. Variation of the extraction constant $\mathrm{K}_{1}$ vs $1 / \varepsilon . \quad \overline{[\mathrm{TDA}}_{i}=0.1$ $\mathrm{M} /$ kerosene, octanol-1 $=$ varies from 5 to $25 \mathrm{v} / \mathrm{v} \%,\left[\mathrm{H}_{2} \mathrm{SO}_{4}\right]=0.041 \mathrm{M}$. $\mathrm{V}_{\mathrm{org}} / \mathrm{V}_{\mathrm{aq}}=1, \mathrm{t}=25^{\circ} \mathrm{C}$.

\subsubsection{Effect of temperature}

The effect of temperature on sulfuric acid extraction has been studied by mixing equal volumes of aqueous phase $\left(\left[\mathrm{H}_{2} \mathrm{SO}_{4}\right]_{i}\right.$ $=0.04 \mathrm{M})$ and organic phase $(0.1 \mathrm{M} \overline{\mathrm{TDA}} /$ kerosene containing $10 \%$ octanol-1) in a thermostatic bath and the mixture was stirred for 15 minutes at different temperatures ranging from 25 to $50^{\circ} \mathrm{C}$. The low sulfuric acid concentration was chosen in order to ensure that all sulfuric acid species extracted will be in the form of $\overline{(\mathrm{TDAH})_{2} \mathrm{SO}_{4}}$.

It is known that the free-energy change, $\Delta G^{\circ}$, for the extraction equilibrium is calculated as follows:

$$
\Delta G^{\circ}=-R T \ln K_{e x},
$$

where $K_{e x}$ is the extraction constant.

The free-energy change $\Delta G^{\circ}$ is related to the enthalpy and entropy changes, $\Delta H^{\circ}$ and $\Delta S^{\circ}$, by the following GibbsHelmholts equation:

$$
\Delta G^{\circ}=\Delta H^{\circ}-T \Delta S^{\circ}
$$

From Eqs. 20 and 21, the following equation can be derived:

$$
\begin{aligned}
\ln K_{e x} & =-\Delta H^{\circ} / R T+\Delta S^{\circ} / R \Longrightarrow \\
\log K_{e x} & =-\Delta H^{\circ} / 2.303 R T+\Delta S^{\circ} / 2.303 R,
\end{aligned}
$$

where $\mathrm{R}$ is the gas constant $\left(8.314 \mathrm{~J} . \mathrm{K}^{-1} \cdot \mathrm{mol}^{-1}\right)$ and $T$ is the temperature in Kelvin.

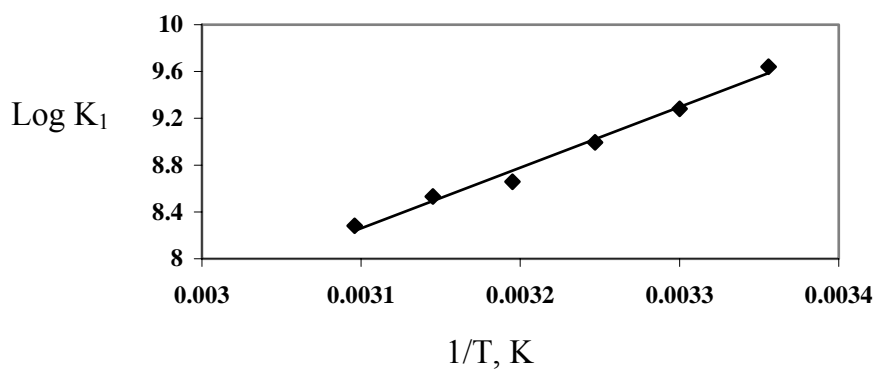

Fig. 6. Variation of the extraction constant $\mathrm{K}_{1}$ vs. (1/T). $\overline{[\mathrm{TDA}}_{i}=0.1$ $\mathrm{M} /$ kerosene $+10 \mathrm{v} / \mathrm{v} \%$ octanol $-1,\left[\mathrm{H}_{2} \mathrm{SO}_{4}\right]_{i}=0.041 \mathrm{M} . \mathrm{V}_{\text {org }} / \mathrm{V}_{\mathrm{aq}}=1, \mathrm{t}=$ varies from 25 to $50{ }^{\circ} \mathrm{C}$.

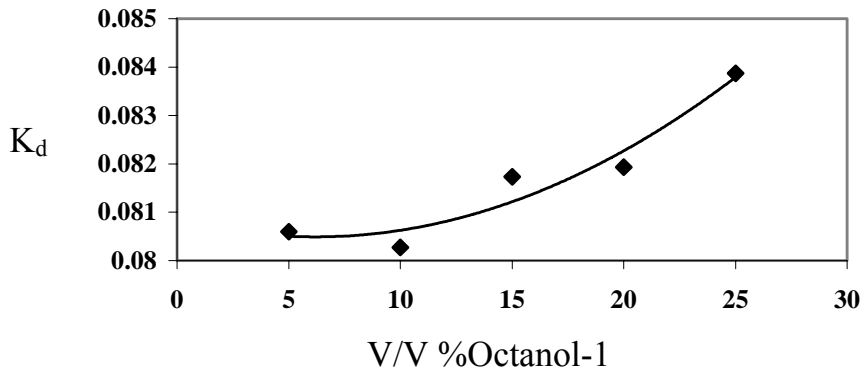

Fig. 7. Variation of $\mathrm{K}_{d}$ vs. octanol-1 percentage in the organic phase. $\overline{[\mathrm{TDA}}_{i}=0.1 \mathrm{M} /$ kerosene , octanol-1 $=$ varies from 5 to $25 \mathrm{v} / \mathrm{v} \%,\left[\mathrm{H}_{2} \mathrm{SO}_{4}\right]=$ $1.06 \mathrm{M}$. $\mathrm{V}_{\text {org }} / \mathrm{V}_{\mathrm{aq}}=1, \mathrm{t}=25^{\circ} \mathrm{C}$.

The results are presented in Fig. 6 in the form of $\log \mathrm{K}_{1}=$ $f(1 / \mathrm{T})$. A straight line has been obtained with a correlation coefficient equal to 0.994 . From the slope and the intercept $\Delta H_{1}^{\circ}$ and $\Delta S_{1}^{\circ}$ for $\overline{(\mathrm{TDAH})_{2} \mathrm{SO}_{4}}$ formation have been calculated and were found to be at $-99.11 \mathrm{~kJ} / \mathrm{mol}$ and $-0.149 \mathrm{~kJ} / \mathrm{mol}$.K, respectively.

\subsection{Extraction of high sulfuric acid concentration}

3.5.1 Determination of equilibrium constant of $\overline{\text { TDAHSO }_{4}}$ formation $\left(\mathrm{K}_{2}\right)$

The extraction of $1.06 \mathrm{M}$ sulfuric acid by $0.1 \mathrm{M}$ tridodecylamine/kerosene containing 5, 10, 15, 20, $25 \%$ octanol-1 was studied at $25{ }^{\circ} \mathrm{C}$ and at an organic to aqueous phase ratio $\left(\mathrm{V}_{\mathrm{org}} / \mathrm{V}_{\mathrm{aq}}=1\right)$.

Fig 7 shows the variation of the distribution coefficient of $\mathrm{H}_{2} \mathrm{SO}_{4}$ against octanol-1 percentage. It is obvious that $\mathrm{K}_{d}$ increases with increasing octanol-1 percentage.

The following equation describes the formation of $\overline{\mathrm{TDAHSO}_{4}}$ :

$$
\overline{(\mathrm{TDAH})_{2} \mathrm{SO}_{4}}+\mathrm{H}^{+}+\mathrm{HSO}_{4}^{-} \stackrel{K_{2}}{\rightleftarrows} 2 \overline{\mathrm{TDAHSO}_{4}} .
$$

The equilibrium constant of Eq. 23 can be written as:

$$
K_{2}=\frac{\overline{\left[\mathrm{TDAHSO}_{4}\right]^{2}}}{\overline{\left[(\mathrm{TDAH})_{2} \mathrm{SO}_{4}\right]}\left[\mathrm{H}^{+}\right]\left[\mathrm{HSO}_{4}^{-}\right]} \text {. }
$$


From the mass balance of tri-n-dodecylamine the following expression can be written:

$$
\overline{[\mathrm{TDA}]_{i}}=\overline{[\mathrm{TDA}]}+2 \overline{\left[(\mathrm{TDAH})_{2} \mathrm{SO}_{4}\right]}+\overline{\left[\mathrm{TDAHSO}_{4}\right]}
$$

Thus,

$$
\overline{\left[\mathrm{H}^{+}\right]}=2 \overline{\left[(\mathrm{TDAH})_{2} \mathrm{SO}_{4}\right]}+2 \overline{\left[\mathrm{TDAHSO}_{4}\right]}
$$

The concentration of $\overline{(\mathrm{TDAH})_{2} \mathrm{SO}_{4}}$ can be calculated from Eq. 6.

$$
\overline{(\mathrm{TDAH})_{2} \mathrm{SO}_{4}}=K_{1} \overline{[\mathrm{TDA}}^{2}\left[\mathrm{H}^{+}\right]^{2}\left[\mathrm{SO}_{4}^{2-}\right] .
$$

The concentration of $\overline{\mathrm{TDAHSO}_{4}}$ can be calculated from Eq. 26.

$$
\overline{\left[\mathrm{TDAHSO}_{4}\right]}=\overline{\left[\mathrm{H}^{+}\right]} / 2-\overline{\left[(\mathrm{TDAH})_{2} \mathrm{SO}_{4}\right]}
$$

Replacing the value of $\overline{(\mathrm{TDAH})_{2} \mathrm{SO}_{4}}$ and $\overline{\mathrm{TDAHSO}_{4}}$ from Eq. 27 and 28 into Eq. 25 gives:

$$
\begin{aligned}
& \overline{[\mathrm{TDA}]_{i}}=\overline{[\mathrm{TDA}]}+2 K_{1} \overline{[\mathrm{TDA}}^{2}\left[\mathrm{H}^{+}\right]^{2}\left[\mathrm{SO}_{4}^{2-}\right]+ \\
& \overline{\left[\mathrm{H}^{+}\right]} / 2-K_{1} \overline{[\mathrm{TDA}]^{2}}\left[\mathrm{H}^{+}\right]^{2}\left[\mathrm{SO}_{4}^{2-}\right]
\end{aligned}
$$

Rearranging Eq. 29 gives:

$$
K_{1}\left[\mathrm{H}^{+}\right]^{2}\left[\mathrm{SO}_{4}^{2-}\right] \overline{[\mathrm{TDA}]^{2}}+\overline{[\mathrm{TDA}]}+\overline{\left[\mathrm{H}^{+}\right]} / 2-\overline{[\mathrm{TDA}]_{i}}=0 .
$$

Thus, knowing the initial concentration of $\overline{\mathrm{TDA}}$ and the concentration of $\mathrm{H}_{2} \mathrm{SO}_{4}$ in the aqueous and organic phases, the equilibrium concentration of $\overline{\mathrm{TDA}}, \overline{(\mathrm{TDAH})_{2} \mathrm{SO}_{4}}$ and $\overline{\text { TDAHSO }_{4}}$ can be calculated from equations 30, 27 and 28, respectively, and finally the equilibrium constant $\mathrm{K}_{2}$ may be obtained from Eq. 24. The plot of Log $\mathrm{K}_{2}$ against octanol-1 percentage in the organic phase gives a curve showing that the equilibrium constant $\mathrm{K}_{2}$ increases with increasing octanol-1 percentage in the organic phase (Fig. 8a). The plot of $\log \mathrm{K}_{2}$ against $1 / \varepsilon$ gives a curve, the straight part of which has a correlation coefficient and a slope equal to -0.96 and -0.91 , respectively (Fig. 8b). From Figs. $8 \mathrm{a}$ and $8 \mathrm{~b}$ we can conclude that the increase of the dielectric constant of the diluent has a more expressed positive effect on sulfuric acid extraction then on the equilibrium constant $\mathrm{K}_{2}$.

\section{V/V \%Octanol-1}

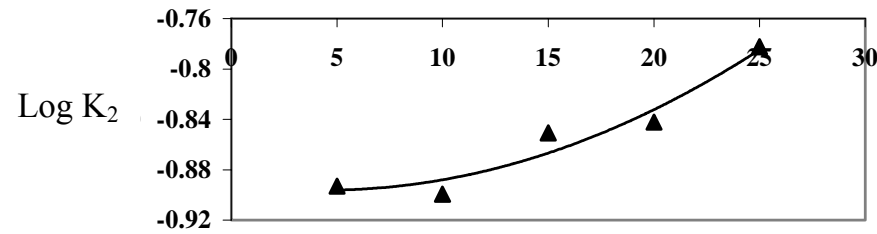

Fig. 8.a. Variation of the extraction constant $\mathrm{K}_{2}$ vs octanol-1 percentage in the organic phase. $\overline{[\mathrm{TDA}}_{i}=0.1 \mathrm{M} /$ kerosene, octanol-1 $=$ varies from 5 to 25 $\mathrm{v} / \mathrm{v} \%,\left[\mathrm{H}_{2} \mathrm{SO}_{4}\right]=1.06 \mathrm{M} . \mathrm{V}_{\mathrm{org}} / \mathrm{V}_{\mathrm{aq}}=1, t=25^{\circ} \mathrm{C}$.

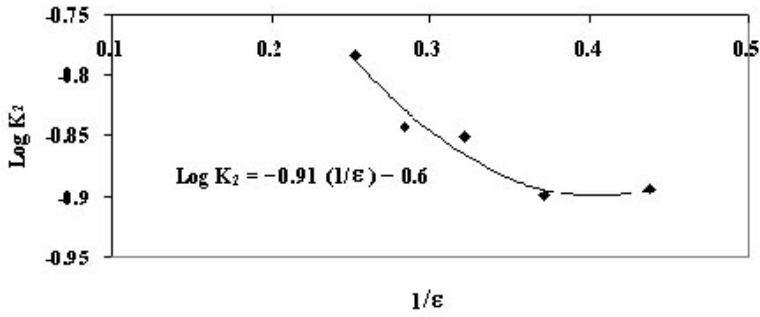

Fig. 8.b. Variation of the extraction constant $\mathrm{K}_{2}$ vs $1 / \varepsilon . \quad \overline{[\mathrm{TDA}}_{i}=0.1$ $\mathrm{M} /$ kerosene, octanol-1 = varies from 5 to $25 \mathrm{v} / \mathrm{v} \%,\left[\mathrm{H}_{2} \mathrm{SO}_{4}\right]=1.06 \mathrm{M} . \mathrm{V}_{\mathrm{org}} / \mathrm{V}_{\mathrm{aq}}$ $=1, \mathrm{t}=25^{\circ} \mathrm{C}$.

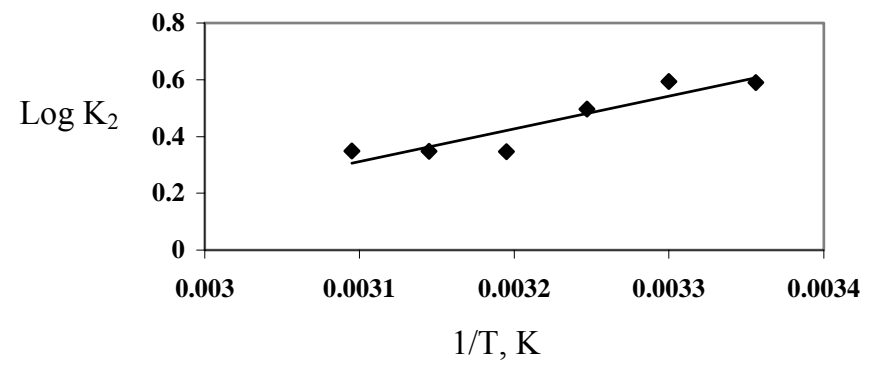

Fig. 9. Variation of the extraction constant $\mathrm{K}_{2}$ vs. (1/T). $\overline{[\mathrm{TDA}}_{i}=0.1$ $\mathrm{M} /$ kerosene $+10 \mathrm{v} / \mathrm{v} \%$ octanol $-1,\left[\mathrm{H}_{2} \mathrm{SO}_{4}\right]_{i}=2.61 \mathrm{M} . \mathrm{V}_{\text {org }} / \mathrm{V}_{\mathrm{aq}}=1, \mathrm{t}=$ varies from 25 to $50{ }^{\circ} \mathrm{C}$.

\subsubsection{Effect of temperature}

The effect of temperature on sulfuric acid extraction has been studied by mixing equal volumes of aqueous phase $\left(\left[\mathrm{H}_{2} \mathrm{SO}_{4}\right]_{i}\right.$ $=2.61 \mathrm{M})$ and organic phase $(0.1 \mathrm{M} \overline{\mathrm{TDA}} /$ kerosene containing $10 \%$ octanol-1) in a thermostatic bath and the mixture was stirred for 15 minutes at different temperatures ranging from 25 to $50^{\circ} \mathrm{C}$. The high sulfuric acid concentration was chosen to ensure that all sulfuric acid extracted species will be in the form of $\overline{\mathrm{TDAHSO}_{4}}$.

The results are presented in Fig. 9 in the form of $\log \mathrm{K}_{2}=$ $f(1 / \mathrm{T})$. A straight line has been obtained with a correlation coefficient equal to 0.93. From the slope and the intercept $\Delta \mathrm{H}_{2}^{\circ}$ and $\Delta S_{2}^{\circ}$ for $\overline{\mathrm{TDAHSO}_{4}}$ formation have been calculated and were found to be $-22.17 \mathrm{~kJ} / \mathrm{mol}$ and $-0.063 \mathrm{~kJ} / \mathrm{mol} . \mathrm{K}$, respectively.

\section{Conclusion}

The extraction of sulfuric acid by $\overline{\mathrm{TDA}} /$ kerosene is influenced by the presence of octanol-1 as modifier in the organic phase, and the value of equilibrium constant of $\overline{(\mathrm{TDAH})_{2} \mathrm{SO}_{4}}$ and $\overline{\mathrm{TDAHSO}_{4}}\left(\mathrm{~K}_{1}\right.$ and $\mathrm{K}_{2}$, respectively) formation increases with increasing octanol-1 percentage in the organic phase. It means that, the increase of dielectric constant of our diluent has a positive effect on sulfuric acid extraction.

The equilibrium constant of $\overline{(\mathrm{TDAH})_{2} \mathrm{SO}_{4}}$ and $\overline{\mathrm{TDAHSO}_{4}}$ formation has been calculated for $10 \% \mathrm{v} / \mathrm{v}$ octanol- 1 at $25{ }^{\circ} \mathrm{C}$ and found to be $10^{9.642} \mathrm{l}^{4} / \mathrm{mol}^{4}$ and $10^{-0.899} \mathrm{l} / \mathrm{mol}$, respectively.

The temperature has a negative effect on the extraction of sulfuric acid by tri-n-dodecylamine, the $\Delta H_{1}^{\circ}$ and $\Delta H_{2}^{\circ}$ for the formation of $\overline{(\mathrm{TDAH})_{2} \mathrm{SO}_{4}}$ and $\overline{\mathrm{TDAHSO}_{4}}$ were found to be $-99.11,-22.17, \mathrm{~kJ} / \mathrm{mol}$ respectively. 
Tab. 1. Nomenclature

\begin{tabular}{l}
$\overline{\mathrm{M}}$ \\
{$\left[\mathrm{H}_{2} \mathrm{SO}_{4}\right]_{i}$} \\
$\overline{\left[\mathrm{H}_{2} \mathrm{SO}_{4}\right]_{t}}$ \\
{$\left[\mathrm{H}_{2} \mathrm{SO}_{4}\right]_{t}$} \\
{$\left[\mathrm{H}_{2} \mathrm{SO}_{4}\right]$} \\
{$\left[\mathrm{H}^{+}\right]$} \\
$\overline{\left[\mathrm{H}^{+}\right]}$ \\
{$\left[\mathrm{SO}_{4}^{2-}\right]$} \\
{$\left[\mathrm{HSO}_{4}^{-}\right]$} \\
$\overline{[\mathrm{TDA}]}{ }_{i}$ \\
$\overline{[\mathrm{TDA}]}$ \\
$\overline{\left[(\mathrm{TDAH})_{2} \mathrm{SO}_{4}\right]}$ \\
$\left.\overline{[\mathrm{TDAHHSO}}{ }_{4}\right]$ \\
$\mathrm{K}_{d}$ \\
$\mathrm{~K}_{1}$ \\
$\mathrm{~K}_{2}$ \\
$\Delta \mathrm{H}^{\circ}$ \\
$\Delta \mathrm{S}^{\circ}$ \\
$\mathrm{T}$ \\
$\mathrm{T}_{1}, \mathrm{~T}_{2}$ \\
$\mathrm{~V}_{\mathrm{org}}$ \\
$\mathrm{V}_{\mathrm{aq}}$ \\
$\varepsilon$ \\
\hline
\end{tabular}

Superscript bar refers to the organic phase.

Concentration in $\mathrm{mol} / \mathrm{L}$.

Initial sulfuric acid concentration in the aqueous phase (M).

Total concentration of sulfuric acid in the organic phase at the equilibrium (M)

Total concentration of sulfuric acid in the aqueous phase at the equilibrium (M).

Equilibrium concentration of undissociated sulfuric acid in the aqueous phase (M).

Equilibrium concentration of $H^{+}$in the aqueous phase (M).

Equilibrium concentration of $H^{+}$in the organic phase (M).

Equilibrium concentration of $\mathrm{SO}_{4}^{2-}$ in the aqueous phase (M).

Equilibrium concentration of $\mathrm{HSO}_{4}^{-}$in the aqueous phase (M).

Initial tri-n-dodecyl amine concentration in the organic phase (M).

Equilibrium concentration of tri-n-dodecylamine in the organic phase (M).

Equilibrium concentration of $\overline{(\mathrm{TDAH})_{2} \mathrm{SO}_{4}}$ in the organic phase (M).

Equilibrium concentration of $\overline{\mathrm{TDAHHSO}_{4}}$ in the organic phase (M).

Distribution coefficient of sulfuric acid $=\frac{\overline{\left[\mathrm{H}_{2} \mathrm{SO}_{4}\right] t}}{\left[\mathrm{H}_{2} \mathrm{SO}_{4}\right]_{t}}$.

Equilibrium constant of equation (5) $\left(\mathrm{L}^{4} / \mathrm{mol}^{4}\right)$.

Equilibrium constant of equation $(23)(\mathrm{L} / \mathrm{mol})$.

Enthalpy of the extraction reaction $(\mathrm{J} / \mathrm{mol})$.

Entropy of the extraction reaction $(\mathrm{J} / \mathrm{mol} . \mathrm{K})$.

Thermodynamic temperature $(\mathrm{K}) . \mathrm{T}$

Initial and final thermodynamic temperatures $(\mathrm{K})$.

Volume of the organic phase.

Volume of the aqueous phase.

Dielectric constant.

\section{References}

1 Coleman CF, Brown KB, Moore JG, Crouse DJ, Solvent Extraction with Alkyl amines, Ind. Eng. Chem 50 (1958), 1756-1762.

2 Coleman CF, Brown KB, Moore JG, Allen KA, Amine salts as solvent extraction reagents for uranium and other metals, Peaceful Uses of Atomic Energy, Basic Chemistry in Nuclear Energy, Geneva. United Nations, 1958, pp. 278-88.

3 Sriram S, Veeraraghavan R, Manchanda VK, Radiochemica Acta 84 (1999), 153-157.

4 latsenko GN, Palant AA, Petrova VA, Tagirov RK, Hydrometallurgy 60 (2001), no. 1, 1-5.

5 Coťar T, Ziyadanoğullari R, Turk. J. Chem. 22 (1998), 379-386.

6 Horn MW, Fraser BG, Pritzker MD, Sep. Sci. Technol. 29 (1994), no. 4, 535-542.

7 Ritcey GM, Ashbrook AW, Solvent Extraction, Principles and Applications to Process Metallurgy, Part 1, Vol. 1, Elsevier publisher, Amsterdam, 1984.

8 Lo TC, Baird MHI, Hanson C, Handbook of solvent extraction, John Wiley \& Sons, Inc, New York, 1983. 